\title{
NEW INFORMATION IN THE EDUCATION SYSTEM AND TECHNOLOGY OF COMMUNICATION
}

\author{
${ }^{1}$ Ruzimurot Kungiratovich Choriev, ${ }^{2}$ Odina Rasulovna Jamoldinovna, ${ }^{3}$ Khudoymurot \\ Chorshanbievich Dusyarov, ${ }^{4}$ Guzal Erkinovna Eshchanova, ${ }^{5}$ Ulugbek Annazarovich Nullaev \\ ${ }^{1}$ Doctor of Pedagogical Sciences, Tashkent Institute of Engineers of Irrigation and Agricultural Mechanization Tashkent, \\ Uzbekistan. \\ ${ }^{2}$ Doctor of Pedagogical Sciences, Professor, Uzbek State University of World Languages, Tashkent, Uzbekistan. \\ ${ }^{3}$ Candidate of Pedagogical Sciences, Associate Professor, Termez State University, Termez, Uzbekistan. \\ ${ }^{4}$ Senior teacher of English Language department, Tashkent Institute of Engineers of Irrigation and Agricultural Mechanization \\ Tashkent, Uzbekistan. \\ ${ }^{5}$ Teacher of English Language department, Tashkent Institute of Engineers of Irrigation and Agricultural Mechanization Tashkent, \\ Uzbekistan.
}

\begin{abstract}
:
An article in the education system, the use of new information and communication technologies in the process of theoretical and practical issues and is described in more detail on the international experience in this field. In the context of the educational system over the past two decades, the problem of improving and modernizing modern information and communication technologies is becoming increasingly relevant. However, to make the learning process less expensive, the introduction of personal computers that are connected to the local network and, therefore, have access to the global (global) Internet, will help accelerate these processes, it was suggested that not only schools should be equipped with modern technologies for the successful implementation of the modernization program, but also that the organizers and teachers of education must have sufficient knowledge in this area
\end{abstract}

Keywords: information communication technologies, distance learning, reproductive technology, interactive technology, casetechnology, technology, asynchronous technologies.

Article Received: 18 October 2020, Revised: 3 November 2020, Accepted: 24 December 2020

\section{Introduction}

Today, our society, our entire way of life, is so developed and intensified that it can even be viewed as an invisible phenomenon. The role of information and communication technologies, which are rapidly entering our lives, is becoming more and more important not only in manufacturing or other fields, but also in the education system. As the President of our country Sh.Mirziyoev noted, "Today, the movement in the modern information space is so intense that it is so far from now that it happened so far away that it cannot be ignored that it has nothing to do with us.

It is certainly possible that hundreds of years of development of such a nation or nation is lagging behind "(Mirziyoev Sh. 2017). Information and communication technologies are not new to anyone at the moment, but the fact that it is constantly improving shows new aspects. As the society is renewed, certain changes and turns occur in every area of the society. This can be explained by the contrast between the previous education system and the current educational system. Therefore, the role of information and communication technologies in the education system is very important.

In order to further enhance the role of information technology in the learning process, various electronic textbooks and e-learning methods have been developed and are still in progress today. It should be noted that at present in the educational system "Distance learning programs" are being developed and widely used information and communication technologies for their implementation.

"We have to clearly realize that it is difficult to achieve our long-term goals without making radical and positive impacts on the 
widespread use of modern ICT in all sectors of the economy and in our daily lives. We should, within a short period of time, not only address the existing shortcomings in many types of information services, but also join the ranks of advanced countries with a high level of implementation of information and communication technologies, President Mirziyoev Sh.

In the context of the educational system's activity over the past two decades, the issue of improving and modernizing modern information and communication technologies is becoming increasingly important. However, in order to make the learning process less expensive, it is connected to a more accessible, local network and therefore has access to the global (global) Internet (Scientific Electronic Journal of International Finance and Accounting. August 4, 2017 www.interfinance.uz 2). The introduction of personal computers accelerated this process.

For successful implementation of the modernization program, which is often based on computer-aided computerization and the Internet, not only educational facilities should be equipped with modern technology, but education organizers and educators must have sufficient knowledge in this area. In fact, there is nothing new about this, but it is necessary to broaden the range of knowledge gained: pedagogical universities are working to train teachers for this specialty, informational classes at schools with computers are available, and not only administrators, but administrators of educational institutions. They are considered to be natural and necessary.
Materials and methods

The goal of every educator, whether a school or a high school teacher, is to improve the quality of teaching, and the use of information and communication technologies can be very helpful. It is also important for the leader to ensure that, in addition to quality, the available technical equipment and other learning resources are accessible to the maximum number of people.

That is why one of them is more focused on affordable and quality education. In order to address the emerging problems, special attention should be paid to the training of pedagogical staff. The use of elements of distance learning is important. Distance learning is a specialized educational services focused on special education for the general population and is based on remote educational information exchange (satellite communication, television, radio, computers, etc.)

The benefits of distance learning are undoubtedly distant. however, the use of new information technologies can solve a number of problems in higher education (Graph 1):

Distance learning tools. In the distance learning process, traditional and innovative learning tools are based on the use of computer technology and telecommunications facilities and other new information technologies. This is known as the modern language of instruction as "software and technical tools of education" (Scientific Electronic Journal "International Finance and Accounting", August 4, 2017, www. Interfinance. uZ $3)$. 


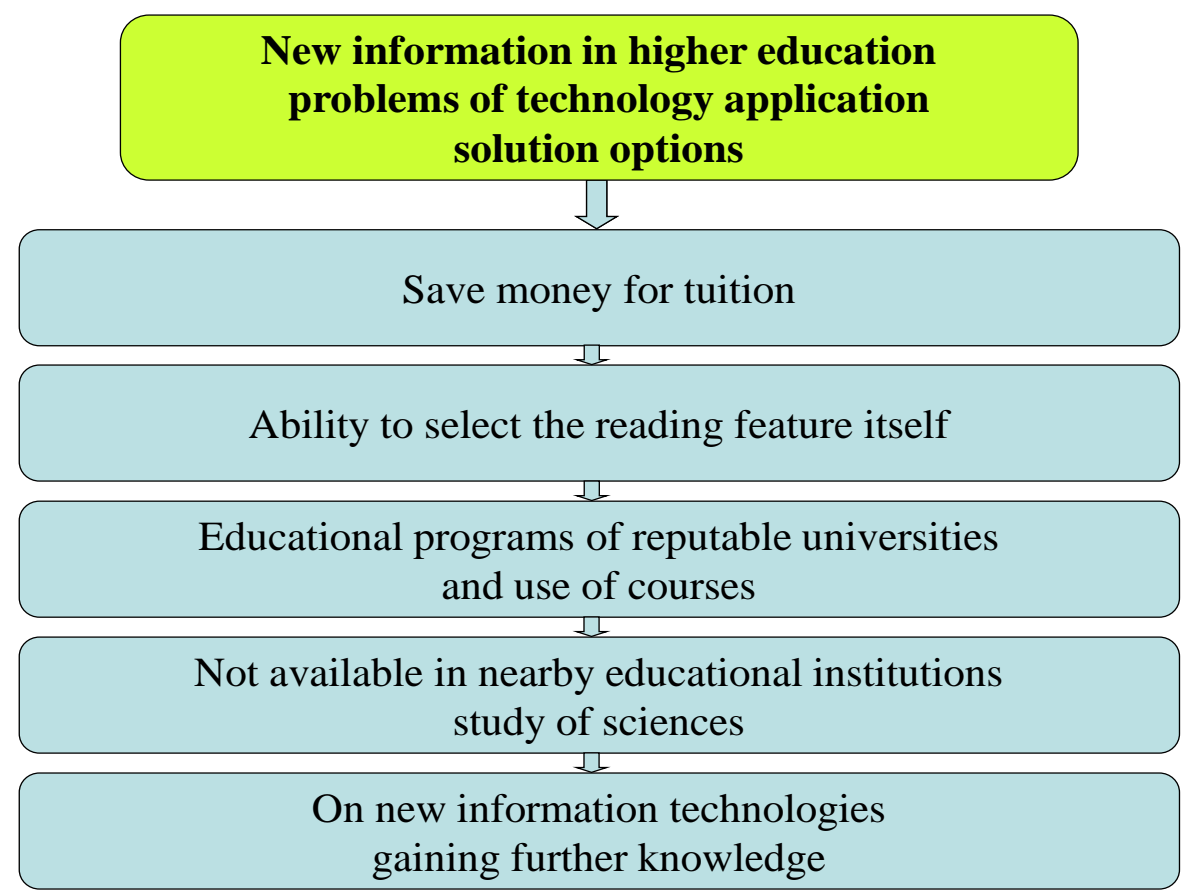

\section{Graph 1. Opportunities to solve the problems of application of new information technologies in higher education}

Distance learning tools. In the distance learning process, traditional and innovative learning tools are based on the use of computer technology and telecommunications facilities and other new information technologies. This is known as the modern language of instruction as "software and technical tools of education" (Scientific Electronic Journal "International Finance and Accounting", August 4, 2017, www. Interfinance. uz 3).

Implemented software and hardware for distance learning should address the following pedagogical tasks:

- Ability to read and pass the computer test;

- Provide a comfortable learning environment;

- Working with students and building relationships through teamwork.

Reproductive technology. Reproductive technologies (teaching materials for dissemination of teaching materials) are more teacher oriented and are based on a learning model. The main purpose of technology is to send information. In order to implement reproductive methodology, it is necessary to use teaching materials and teaching materials first. The classic practice of reproductive technology is TV technology. The modern view of this technology is the use of network technologies. In this case, the use of network technologies to deliver teaching materials, and e-mail for teacherstudent interaction.

Interactive technologies. Interactive distance learning technologies are based on an individual-centered learning model and are primarily focused on acquiring knowledge and skills. The most striking example of interactive technologies is case technology. Modern technologies of interactive technologies are network technologies, as in reproductive technology. It also uses a higher technical form of an individual-oriented model. Computer courses are provided to trainees, and they learn their learning situations by performing e-mail tasks with the teacher (Kenjabaev A. 2015, p. 78).

Collaborative Learning Technologies. Collaborative learning technologies are focused on developing reasoning (analysis, synthesis, evaluation) and aim to apply learning to learning groups. This technology class is intended for use in small groups of students (Scientific electronic journal "International Finance and Accounting" 
August 4, 2017 www.interfinance.uz 4). Dialogue network technologies enable the creation of a multifunctional, team-based, virtual learning environment with a variety of interactivity and information transfer. In this virtual environment, the teamwork of students is controlled by the teacher. Technological platforms.

Technological platforms for distance learning mean a set of software and hardware tools that include the management of training procedures and distance learning processes for distance learning services. Today, technological platforms of distance learning differ from the following main types (Graph 2): TV technology, case-technology, network technologies, Asynchronous technologies and synchronous network technologies. Distance learning technologies should be simplified to achieve efficiency and to replace traditional teaching systems.

Web-based training (WBT) is an independent and team-based learning tool for computer-based interactive learning programs. The main differences between WBTs and CBTs are:

- Training materials are often stored online (rapid change and prompt delivery);
- Monitor and manage student learning activities (control and control of computer-based testing);

- Ability to use individual and group communication tools for different levels of interactivity.

\section{Synchronous network technologies.} Synchronous networking technologies are a modern distance learning technology that allows participants to stay away from each other in the learning process. Simultaneous technologies are designed to create virtual classes using video conferencing tools and interoperability. Simultaneous technologies require all virtual students to participate simultaneously and even effectively integrate different models of learning during one session (International Electronic Journal of Finance and Accounting. August 4, 2017 www.interfinance.uz 6).

The distance learning complex is quite comfortable. But why is distance learning needed? It is natural to ask.

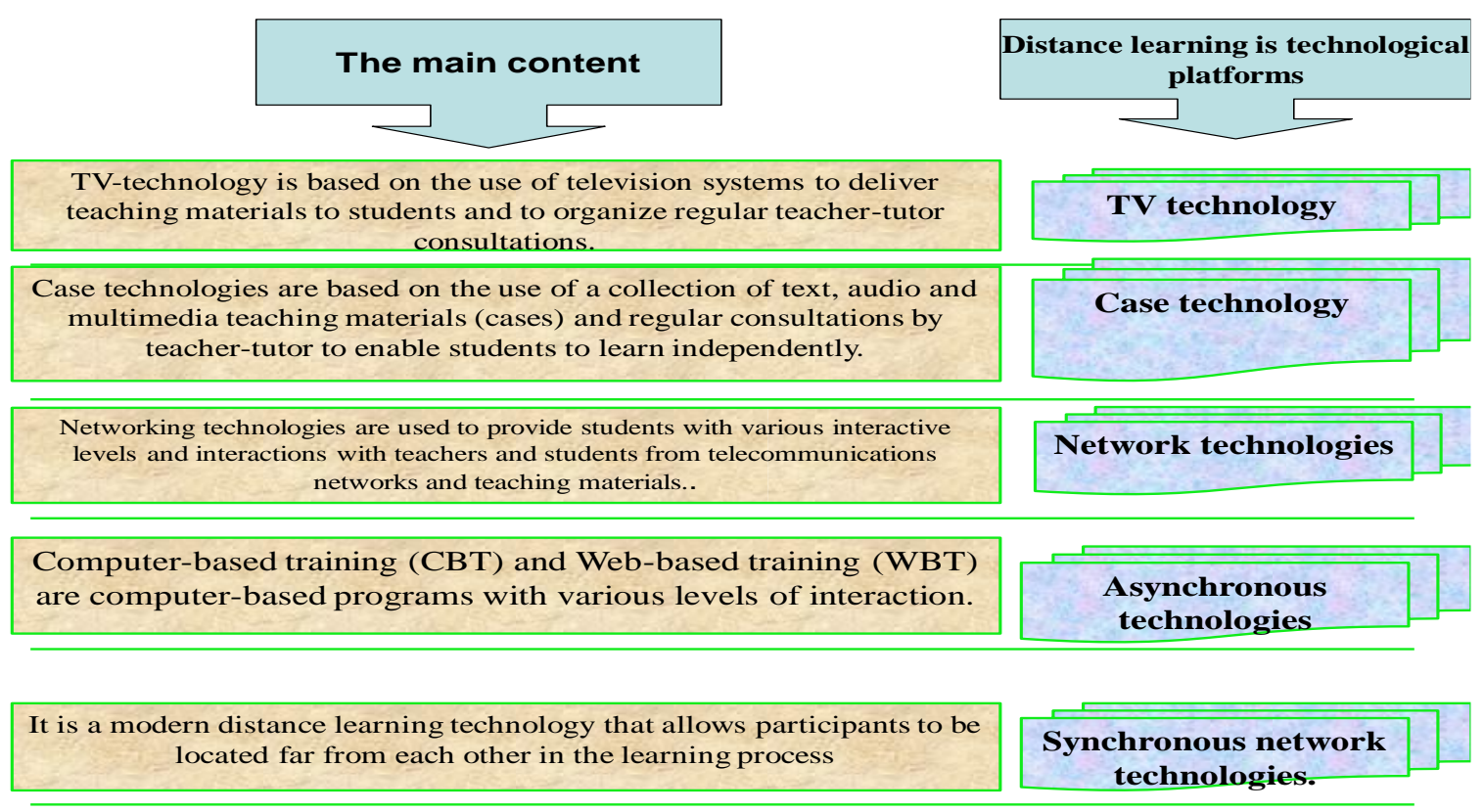

Graph 2: Basic concepts of technological platforms of distance learning 
The answer to this question can be summarized as follows:

1. New opportunities for education (low cost of education, time and place, etc.).

2. Limited enrollment in educational institutions. 3. Increasing the number of people wishing to study.

4. The emergence and development of high-quality information technologies.

5. Increased international integration. The above-mentioned conditions and possibilities show the need for distance learning. In general, the objectives of distance learning are:

- To provide equal access to education for all students, students, and prospective students across the country and abroad.

- Improving the quality of education through the use of the scientific and educational potential of leading universities, academies, institutes, training centers, retraining institutions, professional development institutes and other educational institutions.

- Providing additional education in parallel with basic education and core business activities.

- Meeting the needs of learners and expanding the learning environment.

- Creating lifelong learning opportunities.

- Ensuring a new level of principled education while maintaining the quality of education.

\section{Discussion}

Based on the foregoing, we provide descriptions and definitions of some of the terms that are currently being repeated throughout the educational process. There are different models and forms of distance learning in the education system, which are subject to the following conditions:

- geographical conditions (eg country territory, remote location, climate);

- general level of information and computerization of the country;

- level of development of communications and vehicles;
- the degree of application of information and communication technologies in the learning process;

- availability and potential of scientific and pedagogical staff for the system of distance learning;

- Teaching Traditions, etc. (Scientific Electronic Journal of International Finance and Accounting, August 4, 2017, www. Interfinance.uz 7).

The primary model. In this form of distance learning, there is no need for direct training in the daytime department, and all training is organized at some distance. However, students are in constant contact with teachers attached to it. Local representatives will be formed to advise students and take the final exam. At the same time, the forms and methods of the educational process are freely chosen by the student and the student, the timetable and the training time are not limited. Many open universities are built on the first model of teaching, such as this model of distance learning at the UK Open University (www.open.ac.uk).

Secondary model. Training at the educational institution is conducted both in fulltime and part-time and part-time distance education. Both schedules and training programs are the same. for students, control is assessed using the same criteria. This dual model of distance learning used in an educational institution is not always useful, as most of the training is covered by students. For example, the dual model is used in Australian universities (www.une.edu.au).

Mixed model. This model covers various forms of distance learning, or rather integration of different issues, for example, students receive a part of the course material in parallel with distance learning, while the other directs it in parallel. Some sessions are conducted in the form of virtual seminars, presentations, lectures. The more information and communication technologies are available to an educational institution, the more diverse the forms of 
education can be. These forms of learning are being used at Massey and New Zealand universities (http://massey.ac.nz).

Consortium. This model is based on the interaction of two educational institutions, which is based on the interdisciplinary function of the production of learning materials and their distance learning. While the first institution is engaged in the development of teaching materials for distance learning, the second institution provides the implementation of virtual learning groups teaching tools or distance learning programs. These institutions may be interrelated, universities, or educational centers, faculties, and even businesses and government organizations (Scientific Electronic International Journal of Finance and Accounting, August 4, 2017 www.interfinance.uz 8). The consortium will achieve effective results with strict centralized management, proprietary rights and copyright. This model of teaching is used in Canada, for example, at an open educational agency (http://www.ola.bc.ca).

Franchising. What is a franchise? Franchising (or franchise) is the sale or temporary use of a trademark and / or branding technology (organizational methods) to another entrepreneur. As part of the franchise, two individuals are involved in the relationship. The trademark or technology owner is called the franchisee. A person who buys franchisee rights is called a franchisee. In this process, the set of rights provided by the franchisee to the franchisee is often referred to as the franchisee. According to the current legislation of the Republic of Uzbekistan only franchisee parties can be citizens who are registered as commercial organizations and business entities. In this model, based on the franchisee of distance learning, communication institutions exchange distance courses created by them. The educational institution, which owns a good product in the market of educational services, provides training courses created by other educational institutions, or through distance learning. A distinctive feature of this model is that a student who intends to study at a particular institution will have the opportunity to obtain a diploma of the same size but with a high quality of education through a consortium of mature institutions (Sheikhov A. Pages 4-11, 2008).

Educational institutions based on the franchise model may include Open University Business Higher Education and Eastern European Universities. Validation. This model of distance learning is a common form of teaching. The University, which is open to the franchisee-based educational institutions - the Higher School of Business, and all educational institutions that interact with it, sign an agreement on equal distance learning. Together they create a distance learning program and course, and diplomas and certificates are equally recognized. Summarizing the above, we can say that the introduction of distance learning complex into educational institutions is of great benefit. The system of higher education has all the conditions for its implementation. Eastern European universities. Validation. This model of distance learning is a common form of teaching.

Results

Analyzing the development of information and communication technologies in Uzbekistan, in 2017 the single interactive state services portal introduced 52 new interactive services in 2017. As a result, their total number exceeded 300 . In total, the government provided more than 945,000 services to the public and businesses. The number of operators and service providers in the field of information technology, the speed of international Internet access, and the number of domains in the domain $\mathrm{UZ}$ are growing from year to year. At the same time, the number of business entities engaged in the production of software products is the number of state information resources, the electronic book fund of information library centers, The resources of the ZiyoNet Information Education Network libraries are also growing (Mirziyoev Sh. 2017). 
In 2016, the proportion of the population using the Internet in Uzbekistan was $46.4 \%$, while the number of broadband Internet users in the country was about 1 million 900 thousand people. The index of advanced human capital dropped by $3.5 \%$. This means that much work remains to be done to develop this sector in our countryIn accordance with the Comprehensive Program for Development of Information and Communication System of the Republic of Uzbekistan for 20132020, a phased development of high-speed telecommunication infrastructure for effective functioning of e-government is planned. In particular, it is planned to increase the bandwidth of Internet channels by 2020 and to implement 17 major projects for the development of broadband networks, especially in remote areas. In addition, by 2020 - 22 projects will be implemented to ensure and develop electronic communication of citizens with government agencies (Mirziyoev Sh. 2017).

Today in the country the organization of distance learning with the use of information and communication technologies has begun. This has been mainly implemented in various business training courses, in the system of advanced training and retraining of executives. Problems in the organization of the educational process with the use of information and communication technologies in the field of effective use of pedagogical technologies and thereby improving the quality of education.

\section{Conclusion}

One can say that the effectiveness of such training is proven by experience. World experience shows that most of the newly opened small businesses are closed and liquidated within the first two years, Eight out of ten franchiseebased companies continue to operate five years after the opening. Therefore, it should come as no surprise that $60 \%$ of small businesses in the United States are in franchising. One of the key benefits of franchising is to gain competitiveness and increase the competitiveness of the entire network

This advantage is provided by:

1. Unity of development strategy and uniformity of activity of all participants.

2. Constant sharing of information (ie, being aware of innovative ideas and a fair assessment of the market situation, which in turn increases the level of strategic planning and marketing).

3. Delivery of goods and services on the market (single marketing strategy, general marketing activities, including centralized advertising costs) and determination of the terms of supply (search and finding of suppliers).

4. Successful business models and effective organizational forms for the dissemination and multiplication of modern technologies; "School of Education" for small businesses.

5. Methods of Cooperative Entrepreneurship, which provide practical results. [Ismailova Z. Et al.2019.1175 p].

All higher education institutions of the country are equipped with computers, information and communication technologies. They are all connected to the Internet. The widespread introduction of these technologies in the education system will help to solve many problems faced by universities in a timely manner. The introduction of modern information and communication technologies into the learning environment has contributed to the creation of a new form of learning - distance learning, in addition to traditional teaching methods. In distance learning, students and teachers interact with each other through space-based training courses, forms of surveillance, electronic communication and other Internet technologies. Distance learning based on the use of Internet technology provides access to the global information education network and performs a number of important functions with the principle of integration and interconnection (International Electronic Journal of Finance and Accounting, August 4, 2017 www.interfinance.uz 9) 


\section{References}

[1] Mirziyoev Sh.M. Resolution of the Government of the Republic of Uzbekistan "On Measures for Radical Improvement of Conditions for Radical Development of the Information Technology Sector in the Republic of Uzbekistan" 2017, PF-5099. Tashkent.

[2] Kenjabaev A.T. "Perspectives of IKIT in Economy" Uzbekistan Monograph, Germany 2015 Palmarium academic publishing. P. 78.

[3] Ismailova, Z. K., Khimmataliev, D. O., Khashimova, M. K., Baybaeva, M. K., \& Ergashev, B. B. (2020). Integrative approach to designing the content of secondary specialized vocational education. Opcion, 36(91), 25-41.

[4] Ismailova, Z., Choriev, R., Musurmanova, A., \& Aripjanova, M. (2020). Methods of training of teachers of university on advanced training courses. Journal of Critical Reviews. Innovare Academics Sciences Pvt. Ltd. https://doi.org/10.31838/jcr.07.05.85

[5] Ismailova, Z., Choriev, R., Salomova, R., \& Jumanazarova, Z. (2020). Use of economic and geographical methods of agricultural development. Journal of Critical Reviews. Innovare Academics Sciences Pvt. Ltd. https://doi.org/10.31838/jcr.07.05.84

[6] Ruzimurat Kungratovich Choriev, Muhabbat Fayzievna Khakimova, Oybek Olimovich Daminov, Hasan Ravshanovich Gaffarov, Khayrullo Ergashovich Tuychiev, Nurilla Normirzao'g'li Makhmudov. // Mechanisms of professional competence development for future teachersю

[7] Choriyev R.K. Pedagogical technologies in dual training model // European Journal of Research and Reflection in Educational Sciences Vol. 8 № 1, 2020. ISSN 2056-
5852. - P. 3-66.

[8] Choriyev R.K. Formation of professional competencies of high-tech industry specialists in dual education.// European Journal of Research and Reflection in Educational Sciences. Volume 8 Number 4, 2020 Part II ISSN 2056-5852. - P. 112-114.

[9] Choriyev R.K. Pedagogical technologies in dual training model. // European Journal of Research and Reflection in Educational Sciences, 8 (1) 2020,

- P. 63-66. (13.00.00; № 3)

[10] Zukhra Ismailova, Shirinboy Olimov, Durdona Mustafoeva, Yulduz Yarmanova, Nargiza Temirkulova. (2020). Technology Of Diagnostic Level Of Development Of Professional Competence Of Pedagogical Personnel In The System Of Training. International Journal of Advanced Science and Technology, 29(7), 3337-3343. Retrieved from http://sersc.org/journals/index.php/IJAST/ article/view/21886

[11] Zukhra Ismailova, Olim Turakulov, Shakhnoz Samieva, Igamberdi Tufliev, Abdakim Mamataliev. (2020). Technology, Content, Form And Methods Of Independent Work Of Students In Modern Conditions. International Journal of Advanced Science and Technology,29(7), 3344-3348. Retrieved from

http://sersc.org/journals/index.php/IJAST/ article/view/21887

[12] Khimmataliev D., Khakimov J., Daminov O., Rakhmatova F. Criteria and indicators for assessing the level of professional training of future teachers of vocational training at a training module // Journal of critical reviews. ISSN - 2394-5125. Vol 7, Issue 5, 2020 - p. 428-431. doi:10.31838/jcr.07.05.89 
[13] Khimmataliev D.O. Integration of pedagogical and technical knowledge in the diagnosis of preparation for professional activity. Monograph. Tashkent, Uzbekistan, 2018 - 168 p.

[14] Khimmataliev D.O. Integration of pedagogical and technical knowledge in the diagnosis of professional training: Doctorate in Pedagogical Sciences (DSc) diss. avtoref. - $\mathrm{T} .: 2018$. -70 b 120

[15] Khimmataliev D.O. Integration of scientific knowledge in preparation for the professional activities of future teachers of vocational education // School of the future. Moscow, 2016. No. 6. -S. 50-54.

[16] Olimov K. T. et al. Competent training of future specialists on the basis of acmelogical approach //Journal of Critical Reviews. - 2020. - T. 7. - №. 15. - P. 2476-2483.

[17] Olimov K. T et al..Introduction of dual training in the system of continuous professional education. European Journal of Research and Reflection in Educational Sciences// -2020. Volume 7 Number 12, 2019 Part VI. P. 509-512

[18] Olimov K. T. et al. Teaching Special Subjects for Students with Disabilities in
Preparation for the Profession by Using Innovative Educational Technologies //International Journal of Innovative Technology and Exploring Engineering (IJITEE). - 2019. - T. 9. - C. 425-429.

[19] www.open.ac.uk - UK Open University

[20] www.une.edu.au - University of Australia

[21] http://massey.ac.nz - University of New Zealand

[22] http://www.ola.bc.ca - Canadian Open Education Agency

[23] International Electronic Journal of International Finance and Accounting. No. 4, August 2017 www.interfinance.uz.8. Shaykhov's A.E. under general edit. Franchising Guide for Entrepreneurs of Uzbekistan Methodical Guide. Tashkent, 2008 Pages 4-11. Website: www.chamber.uz, www.bfu.uz.

[24] Ismailova Z. Et al. The use of innovation technologies in the formation of students' professional competences. International joburnal of ingenering and advanced technology (tm) Volume-9 1ssue-1. October.2019.1175 p. 